\title{
Giant cell arteritis (temporal arteritis) affecting the breast: report of two cases and review of published reports
}

\author{
Robert J R McKendry, Maha Guindi, Donald P Hill
}

\begin{abstract}
The breast is an infrequently recognised site of primary giant cell arteritis. Two cases of giant cell arteritis affecting the breast are described and 11 previously described cases are reviewed. All cases presented with single or multiple breast masses, leading to a diagnosis before biopsy of suspected breast carcinoma. Symptoms similar to those of polymyalgia rheumatica occurred in about half of these patients, though the significance of these symptoms was only appreciated in retrospect. Clinical or pathological evidence of giant cell arteritis outside the breast (temporal artery, thyroid artery) was noted in a minority of cases. Seven patients received corticosteroid treatment, and all patients recovered without complications. Two patients had an adenocarcinoma of the breast contiguous with the giant cell arteritis.

Giant cell arteritis affecting the breast may be underrecognised and should be considered in older women with polymyalgia rheumaticalike symptoms and tender breast mass(es).
\end{abstract}

The clinical picture of temporal arteritis has expanded considerably since 1932 when Bayard Horton et al described two patients with fever, weight loss, scalp tenderness, and temporal artery biopsies indicating arteritis. Since then 'temporal' arteritis has been described affecting the proximal aorta and all of its major arterial branches. Typically it affects subjects over the age of $\mathbf{5 0}$ and is usually associated with a raised erythrocyte sedimentation rate. The well recognised symptoms and signs are caused by arterial inflammation or by arterial occlusion, or both. The symptoms include temporal headaches, scalp tenderness, loss of vision, jaw claudication and in some patients proximal muscle aching, stiffness, anorexia, and fever characteristic of an associated polymyalgia Department of Medicine, Division of Rheumatology and Department of Laboratory Medicine, Ottawa General Hospital, Ontario, Canada

R J R McKendry

M Guindi

D P Hill

Correspondence to: Dr Robert McKendry, Rheumatic Diseases Unit, Ottawa General Hospital, Ottawa Genera

501 Smyth Road

Ottawa, Ontario, Canada

K1H 8L6.

Accepted for publication

29 January 1990 rheumatica syndrome. The term temporal arteritis has gradually been replaced by giant cell arteritis - a recognition of the more widespread distribution of arteritis and the presence of multinucleated giant cells in most arterial biopsy specimens.

Giant cell arteritis affecting the breast, described initially by Waugh in 1950 , remains one of the less recognised variants of giant cell arteritis. ${ }^{1}$ It usually presents as one or more breast masses and may mimic breast carcinomaparticularly in the absence of other more familiar features of the giant cell arteritis/polymyalgia rheumatica syndrome. We present two new cases of giant cell arteritis affecting the breast and review the 11 previously described. ${ }^{1-11}$

\section{Case reports}

CASE 1

A 64 year old French Canadian woman was referred to the Ottawa General Hospital Cancer Clinic in November 1983 with a one month history of bilateral tender breast lumps. The patient noted erythematous skin over some of the tender lumps. Her doctor prescribed phenylbutazone, pethidine, and ice packs to control the pain. She had no other symptoms of giant cell arteritis, although three months earlier an investigation for left carotid stenosis had been carried out. Constitutional symptoms suggestive of polymyalgia rheumatica, including anorexia, weight loss, and lethargy, were initially attributed to insomnia secondary to breast pain.

Examination showed five firm tender masses over the medial and lateral upper quadrants of both breasts - the largest measuring $3 \times 3 \mathrm{~cm}$. Peripheral pulses were palpable and a III/IV left carotid bruit was noted. The temporal arteries were not examined. Investigations included a haemoglobin concentration of $121 \mathrm{~g} / \mathrm{l}$, white blood cell count of $10500 \times 10^{9} / 1$, and mammograms showing very mild fibrocystic dysplasia. A sedimentation rate was not determined. Biopsy specimens of one lesion from each breast showed extensive necrotising arteritis with acute, subacute, and chronic inflammatory reaction in vessel walls of both specimens and a few giant cells (fig 1). She was discharged from hospital and no drugs were given. A month later she had several palpable, non-tender breast masses and no other clinical evidence of giant cell arteritis or polymyalgia rheumatica. Six months later she was still free from symptoms, her breast masses had disappeared, and the left carotid bruit remained unchanged. No medical problems developed during the four year follow up.

\section{CASE 2}

A 60 year old doctor's mother presented with a painful, erythematous mass over the lateral aspect of her left breast. The preoperative diagnosis of breast cancer was strengthened by a family history of three sisters with breast cancer. Three months previously she had experienced crampy abdominal pain, bloodless diarrhoea, anorexia, weight loss of $9.5 \mathrm{~kg}$, and a low grade fever. Investigations showed stool cultures positive for campylobacter. The abdominal pain and diarrhoea resolved coincident with erythromycin treatment, but the anorexia and low grade fever continued. She developed night sweats and 'bone pain' in both thighs just before excision biopsy of her left breast mass. Preoperative tests showed 


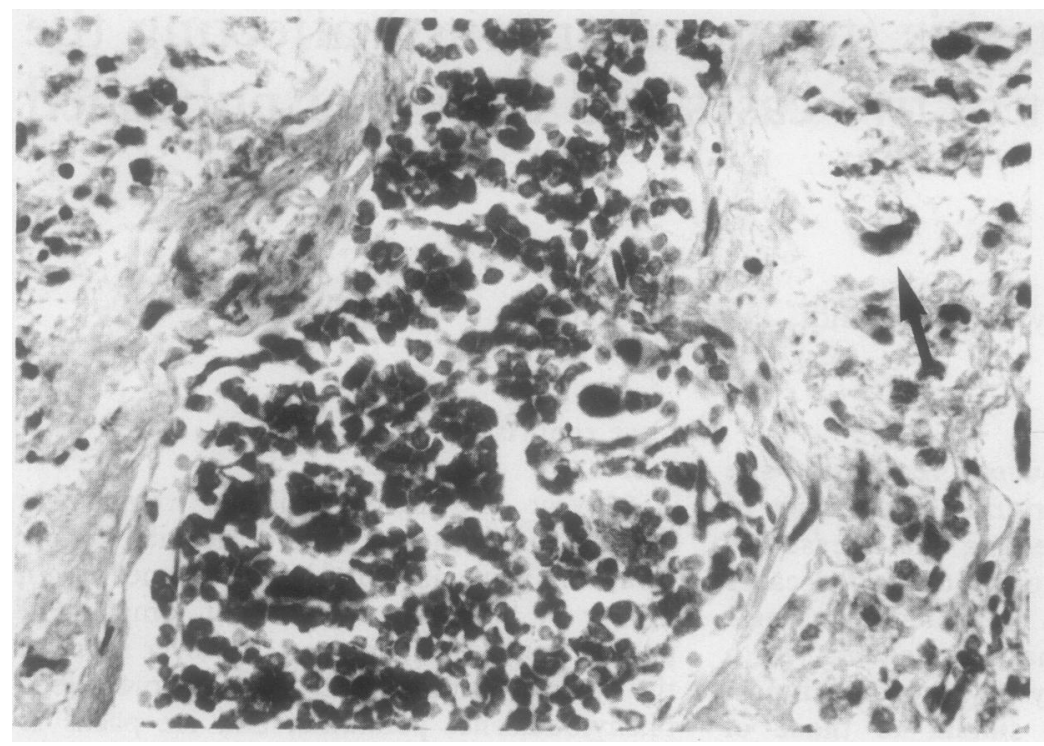

Figure 1 Inflammatory infiltrate of a vessel wall including a giant cell (arrow). Opposite wall shows necrosis.

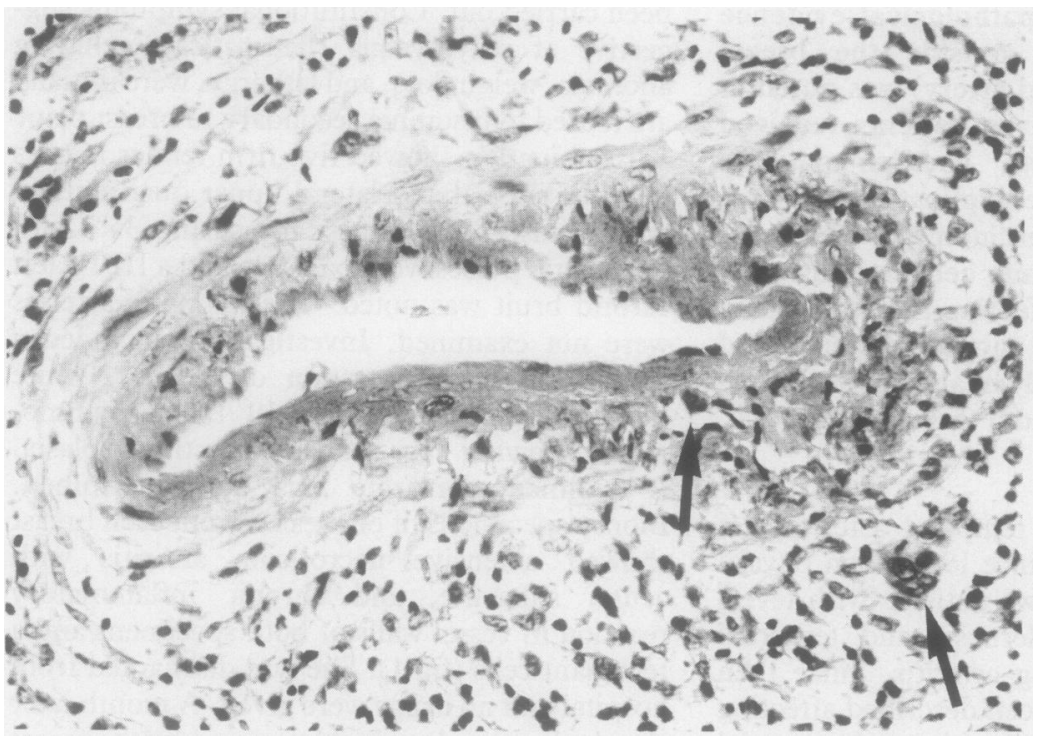

Figure 2 Necrotising vasculitis affects a segment of the vessel wall and includes a giant cell (arrow). The adventitia shows cellular exudate including a giant cell (arrow).

haemoglobin $97 \mathrm{~g} / 1$, white blood cell count $13600 \times 10^{9} / 1$, and sedimentation rate $56 \mathrm{~mm} / \mathrm{h}$ (Wintrobe). The excision biopsy showed necrotising vasculitis, with a few giant cells and was interpreted by a panel of pathologists as 'suggestive of polyarteritis nodosa' (fig 2). Postoperative investigations were negative for antinuclear antibody and hepatitis $B$ antigen and antibody. Treatment with prednisone $60 \mathrm{mg}$ daily, tapered to $10 \mathrm{mg}$ three times a day over three weeks resulted in resolution of her fever, 'bone pain', and night sweats within 48 hours. Three weeks after discharge from hospital she was completely free from symptoms. Her haemoglobin was $118 \mathrm{~g} / \mathrm{l}$ and sedimentation rate $22 \mathrm{~mm} / \mathrm{h}$. The prednisone dose was decreased to $10 \mathrm{mg}$ twice a day. In January 1988 she was referred to the Ottawa General Hospital rheumatic disease unit for further definition of the nature and extent of her vasculitis. Clinical evalution confirmed that she had never experienced temporal headaches, scalp tenderness, jaw claudication, or visual symptoms. Interestingly, her brother had developed biopsy proved giant cell arteritis at the age of 57. Results of extensive investigations, including sinus radiographs, electromyography, nerve conduction studies, renal and coeliac axis angiography, and muscle biopsy, were all normal, except for some type II muscle atrophy attributed to prednisone treatment. She remained free from symptoms or signs of vasculitis during the five month follow up. Polyarteritis nodosa or Wegener's granulomatosis were considered unlikely as other systems were not affected and because the patient's improvement was rapid and sustained. The diagnosis of giant cell arteritis is supported by the patient's polymyalgia rheumatica-like symptoms, the family history of giant cell arteritis, consistent biopsy histology, and her response to treatment.

\section{Discussion}

Since Waugh described the first case of 'bilateral mammary arteritis'1 at least 11 other cases of giant cell arteritis affecting the breast(s) have been described. ${ }^{2-11}$ Several other cases of necrotising arteritis of the breast were identified as possible cutaneous polyarteritis nodosa, ${ }^{12}$ related to Wegener's granulomatosis ${ }^{13-16}$ or undifferentiated. ${ }^{17}$ Waugh chose the term 'mammary arteritis' because he recognised that both existing terms-temporal arteritis and giant cell arteritis-were misleading, as neither temporal artery disease nor the presence of giant cells was essential to define the form of arteritis bearing these names. The same problem exists today. The term giant cell arteritis is in common use and is used here to define patients in whom the clinical and pathological evidence is most consistent with the syndrome of giant cell arteritis, even though giant cells were not present in all previously described cases.

The table summarises the clinical features of 11 previously described patients and those of our two patients. The women were between 52 and 79. years of age and in five cases masses were detected in both breasts. Although clinical evidence of breast inflammation was a feature of most cases, some patients presented with nontender masses. In most instances the diagnosis before biopsy was probable breast carcinoma. In restrospect at least three patients had features of polymyalgia rheumatica and nine had a raised sedimentation rate. In one case histological changes consistent with giant cell arteritis were also noted in the thyroid gland. ${ }^{6}$ Temporal artery biopsy in one case showed characteristic changes of giant cell arteritis, even though there was no clinical evidence of temporal artery inflammation. ${ }^{7}$ In another case a normal temporal artery biopsy and the presence of acute necrotising periarteritis in a triceps muscle biopsy specimen persuaded the authors to diagnose polyarteritis nodosa, even though panarteritis with giant cells was noted in the breast biopsy specimen and the patient had symptoms and signs of polymyalgia rheumatica. ${ }^{3}$ Yet another case was diagnosed as 'focal arteritis' of the breast, even though the referring doctor had diagnosed temporal arteritis and the 
Clinical features of patients with giant cell arteritis affecting the breasts

\begin{tabular}{|c|c|c|c|c|c|c|}
\hline Reference & Age & Breast examination & $\underset{(\operatorname{mon} / h)}{E S R^{*}}$ & Other features & $\begin{array}{l}\text { Duration of } \\
\text { follow up }\end{array}$ & Treatment \\
\hline 1 & 64 & $\begin{array}{l}\text { R upper medial breast non-tender } \\
1.3 \mathrm{~cm} \text { lump } \\
\mathrm{L} \text { breast firm, fixed, tender, } \\
2 \times 3 \mathrm{~cm} \text { lump }\end{array}$ & 40 & $\begin{array}{l}\text { Slight normochromic anaemia } \\
(84 \%)\end{array}$ & $16 \operatorname{mos}$ & $\begin{array}{l}\text { R mastectomy, L lumpectomy, } \\
\text { No drugs }\end{array}$ \\
\hline 2 & 66 & Multiple, bilateral breast lumps & 18 & $\begin{array}{l}\text { Occasional headaches, dizziness, } \\
\text { burning sensation in hands. } \\
\text { Diagnosed as temporal arteritis } \\
\text { by referring doctor }\end{array}$ & $14 \operatorname{mos}$ & $\begin{array}{l}\text { Headaches improved with prednisone } \\
60 \mathrm{mg} \text {. Recovered over } 3 \text { months }\end{array}$ \\
\hline 3 & 72 & $\mathrm{~L}$ breast, tender $2 \times 3 \mathrm{~cm}$ lump & 112 & $\begin{array}{l}\text { PMR*-like syndrome after breast } \\
\text { biopsy-ie, muscle weakness, } \\
\text { night sweats } 6.8 \mathrm{~kg} \text { weight loss. } \\
\text { No bruits. Temp } 37 \cdot 2-38 \cdot 6^{\circ} \mathrm{C} \text {. } \\
\mathrm{R} \text { temporal artery and } \mathrm{R} \text { triceps } \\
\text { biopsy normal }\end{array}$ & 8 yrs & $\begin{array}{l}\text { Prednisone } 40 \text { mg. Within } 24 \mathrm{hrs} \\
\text { temperature and muscle pain } \\
\text { decreased }\end{array}$ \\
\hline 4 & 59 & $\begin{array}{l}L \text { breast lump } \\
R \text { breast, firm, fixed } 4 \times 3 \mathrm{~cm} \\
\text { lump }\end{array}$ & 98 & $\begin{array}{l}\text { PMR-like symptoms for } 2 \text { wks, } \\
\text { swollen } R \text { ankle. Hepatitis B } \\
\text { negative }\end{array}$ & $20 \mathrm{mos}$ & $\begin{array}{l}\text { Spontaneous improvement without } \\
\text { treatment }\end{array}$ \\
\hline 5 & 72 & $\begin{array}{l}\text { Multiple, bilateral } 1 \times 2 \mathrm{~cm} \text { tender } \\
\text { breast lumps }\end{array}$ & 124 & Fever $38 \cdot 3^{\circ} \mathrm{C} .31 / 2 \mathrm{~kg}$ weight loss & $>2$ yrs & $\begin{array}{l}\text { Prednisone } 40 \mathrm{mg} \text { for } 4 \text { days. } \\
\text { Improved dose tapered over } 6 \text { mos. } \\
\text { Followed by recurrence of lump and } \\
\text { increased ESR }\end{array}$ \\
\hline 6 & 62 & $\begin{array}{l}\text { Multiple, bilateral small slightly } \\
\text { tender lumps }\end{array}$ & 85 & $\begin{array}{l}\mathrm{L} \text { thyroid biopsy showed adenoma } \\
\text { and arteritis }\end{array}$ & $2 \mathrm{mos}$ & $\begin{array}{l}\text { Prednisone } 40 \mathrm{mg} \text {. Patient improved } \\
\text { and ESR decreased }\end{array}$ \\
\hline 7 & 79 & $\begin{array}{l}R \text { breast } 2 \times 5 \mathrm{~cm} \text { hard, } \\
\text { mobile lump }\end{array}$ & $70-82$ & $\begin{array}{l}\text { Flu-like polyarthralgias and } \\
\text { proximal stiffness. Temporal } \\
\text { artery biopsy after several weeks } \\
\text { of prednisone treatment }\end{array}$ & $18 \mathrm{mos}$ & $\begin{array}{l}\text { R mastectomy. Axillary dissection } \\
\text { temporal artery biopsy, and } \\
\text { prednisone } 60 \mathrm{mg}\end{array}$ \\
\hline 8 & 52 & No discrete lumps & 94 & $\begin{array}{l}\text { Needle apiration, 'benign ductal } \\
\text { cells'. Haemoglobin } 109 \mathrm{~g} / 1 \text {. } \\
\text { Biopsy done to rule out } \\
\text { inflammatory breast carcinoma }\end{array}$ & $14 \mathrm{mos}$ & Prednisone $\mathbf{4 0} \mathrm{mg}$ \\
\hline 9 & 68 & $\begin{array}{l}\text { L_3 week history of a painful } \\
\text { irregular breast lump in the } \\
\text { upper quadrant measuring } \\
3-4 \mathrm{~cm} \text { in diameter }\end{array}$ & $60+$ & & 5 wks & No specific treatment \\
\hline This study & 64 & $\begin{array}{l}\text { Five tender breast lumps; two in } \\
R \text { and three in } L \text { breast, } \\
\text { largest measuring } 3 \times 3 \mathrm{~cm}\end{array}$ & NA & $\begin{array}{l}\text { Breast masses, very tender, } \\
\text { erythematous }\end{array}$ & $4 \cdot 5$ yrs & No specific treatment \\
\hline This study & 60 & $L$ breast lump & 56 & $\begin{array}{l}\text { Fever, weight loss, fatigue, } \\
\text { stiffness. Abdominal } \\
\text { angiography and muscle biopsy. } \\
\text { Brother had GCA* }\end{array}$ & 5 wks & Prednisone $60 \mathrm{mg}$ tapered \\
\hline 10 & 68 & $R$ breast lump, $0.5 \mathrm{~cm}$ & 65 & $\begin{array}{l}\text { Neck and shoulder stiffness for } \\
1 \text { yr, stiffness in thigh adductor } \\
\text { muscles. No symptoms/signs of } \\
\text { temporal arteritis. No } \\
\text { improvement after } 3 \text { days of } \\
\text { prednisone } 30 \text { mg. Temporal } \\
\text { artery biopsy normal }\end{array}$ & $14 \mathrm{mos}$ & $\begin{array}{l}\text { Diclofenac } 50 \mathrm{mg} \text { three times a day. } \\
\text { Physiotherapy. Breast irradiation } \\
\text { for coexisting ductal carcinoma }\end{array}$ \\
\hline 11 & 54 & $\begin{array}{l}\mathrm{L} \text { breast, } 2 \text { tender lumps } 0.2 \\
\text { and } 1.5 \mathrm{~cm}\end{array}$ & NA & No constitutional symptoms & $8 \mathrm{mos}$ & No specific treatment \\
\hline
\end{tabular}

*ESR = erythrocyte sedimentation rate; $P M R=$ polymyalgia rheumatica; $G C A=$ giant cell arteritis. tOne month after biopsy.

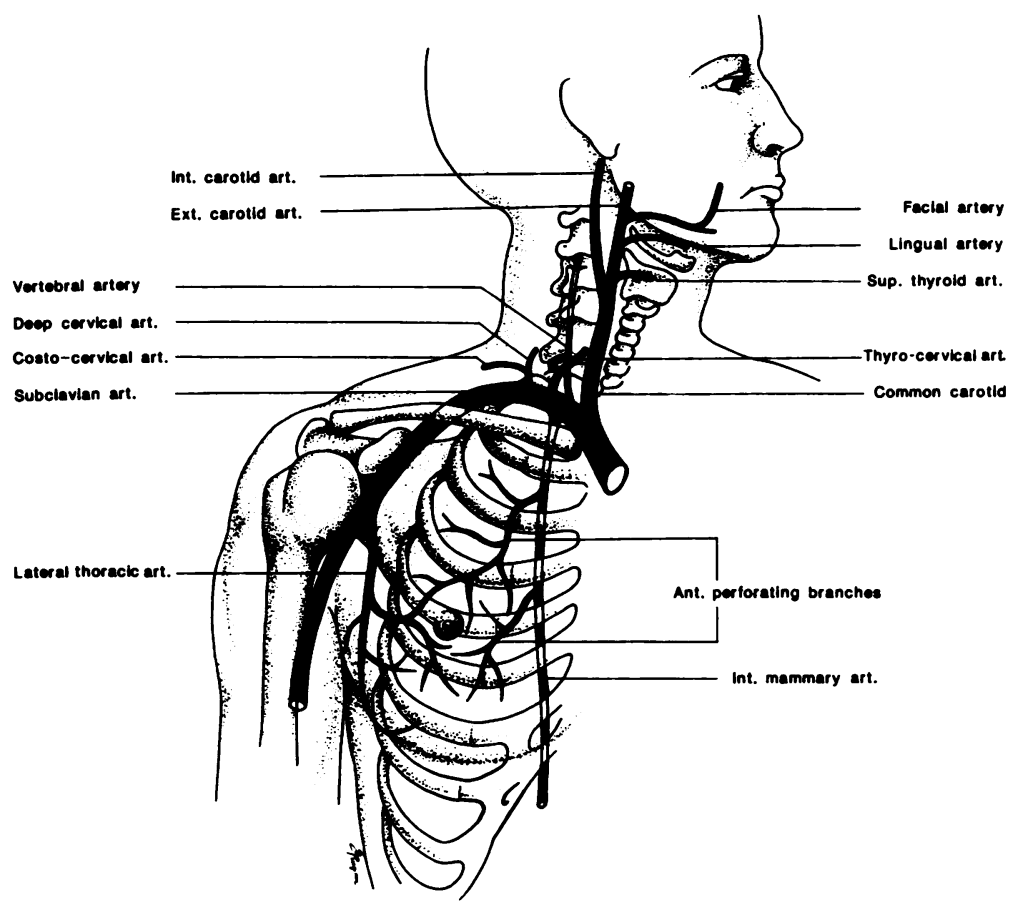

Figure 3 Main arterial supply of the breast and adjacent main branches of the subclavian artery. patient's headaches were relieved with prednisone. ${ }^{2}$ None of these patients developed multisystem disease characteristic of Wegener's granulomatosis or polyarteritis nodosa during an average follow up period of 22.4 months (range five weeks to eight years). In all treated patients the size and tenderness of the breast masses, the sedimentation rate, and symptoms of polymyalgia rheumatica decreased over several weeks with tapering doses of prednisone. Four patients improved without corticosteroid treatment. ${ }^{14911}$ In one case tender breast lumps and a raised sedimentation rate recurred when prednisone was discontinued after six months of treatment. ${ }^{5}$

Giant cell arteritis of the breast cannot be easily differentiated clinically from carcinoma of the breast. The sudden onset of symptoms, absence of regional lymphadenopathy, and the presence of multifocal lesions in some cases should suggest the possibility of arteritis. Two reports of breast carcinoma and giant cell arteritis of the breast in contiguous segments of the same specimen, however, illustrate the importance of an excision biopsy. ${ }^{7}{ }^{10}$ Superficial thrombophlebitis of the breast-Mondor's disease-usually presents as tender subcutan- 
eous cords rather than ovoid masses. ${ }^{18}$ At least two cases diagnosed as Mondor's disease had histological changes of resolving arteritis, however, including giant cells in one instance. ${ }^{19}$ Wegener's granulomatosis is also a rare cause of granulomatous arteritis of the breast, coinciding with pulmonary disease. ${ }^{13-16}$ Weber-Christian disease, ${ }^{20}$ fat necrosis, ${ }^{21}$ and sarcoidosis, ${ }^{22} 23$ are other rare causes of breast pain simulating a neoplasm. Unfortunately, the histology of giant cell arteritis is not sufficiently unique to differentiate it clearly from other forms of necrotising arteritis. The presence of giant cells is usual (10 of 13 cases in the table), but giant cells are seen in other forms of vasculitis and may be absent in otherwise typical cases of giant cell arteritis. The spectrum of acute to chronic vasculitis, illustrated by case 1 , suggests that giant cell arteritis cannot be reliably differentiated from polyarteritis nodosa by histological criteria alone.

The breast is supplied mainly by two branches of the subclavian artery-the medial side by the internal mammary artery and the lateral aspect by the lateral thoracic artery (fig 3). As giant cell arteritis has been described in all other major branches of the subclavian artery it is perhaps surprising that giant cell arteritis affecting the breast is not recognised more often. Symptoms and signs of giant cell arteritis caused by compromised blood flow-for example, blindness and claudication, might not be expected to produce symptoms in the richly vascularised breast. In fact the internal mammary artery flow can be completely diverted into the myocardium (Vineberg procedure) without deleterious effects. Because tender breast lumps are a common symptom of benign fibrocystic disease of the breast their occurrence may be underreported by patients and underinvestigated by doctors, unless the degree of inflammation is extraordinary. The fact that some breast lumps caused by giant cell arteritis are non-tender creates another possible source of underreporting.

Clinical examination of the breasts should be added to the standard evaluation of all women suspected of having polymyalgia rheumatica or giant cell arteritis, or both. Apart from the temporal arteries the breasts offer the only other reasonably accessible tissue for biopsy in suspected cases of giant cell arteritis. The rapid and sustained response to prednisone treatment and the importance of excluding more generalised forms of necrotising arteritis or carcinoma are compelling reasons to consider giant cell arteritis in the breast and carry out an excision biopsy.

1 Waugh T R. Bilateral mammary arteritis. Report of a case. Am F Pathol 1950; 26: 851-61.

2 McCarty D J, Imbrigia J, Hung J K. Vasculitis of the breasts. Arthritis Rheum 1968; 11: 796-801.

3 Dega F J, Hunder G G. Vasculitis of the breast. An unusual manifestation of polyarteritis. Arthritis Rhewm 1974; 17: 973-6.

4 Potter B T, Housley E, Thomson D. Giant cell arteritis mimicking carcinoma of the breast. $\mathrm{Br} M e d \mathcal{F} 1981 ; 282$ : 1665-6.

5 Thaell J F, Saue G L. Giant cell arteritis involving the breasts. F Rheumatol 1983; 10: 329-31.

6 Stephenson T J, Underwood J C E. Giant cell arteritis: an unusual cause of palpable masses in the breast. $\mathrm{Br} \mathcal{J}$ Surg 1986; 73: 105 .

7 Horne D, Crabtree T S, Lewkonia R A. Breast arteritis in polymyalgia rheumatica. $\mathcal{F}$ Rheumatol $1987 ; 14$ : 613-5.

8 Cook D J, Bensen W G, Carroll J J, Joshi S. Giant cell arteritis of the breast. Can Med Assoc F 1988; 139: 113-5.

9 Nirodi N S, Stirling W J I, White M F I. Giant cell arteritis presenting as a breast lump. Br f Clin Pract 1985; 39: 84-6.

10 Clement $P$ B, Senger H S, How A. Giant cell arteritis of the breast: case report and literature review. Hum Pathol 1987; 18: 1186-9.

11 Chaitin B, Kohout N D, Goldman R L. Focal arteritis of the breast. Angiology 1981; 32: 334-7.

12 Levy A, Weinberger A, Mor C, Pinkhas J. Localized polyarteritis nodosa: cases involving the lower extremities polyarteritis nodosa: cases involving the lower
and the breast. Rhewomatol Int 1986; 6: 43-4.

13 Elsner B, Harper F B. Disseminated Wegener's granulomatosis with breast involvement: report of a case. Archives of Pathology 1969; 87: 544-7.

14 Pambakian H, Tighe J R. Breast involvement in Wegener's granulomatosis. F Clin Pathol 1971; 24: 343-7.

15 Kuhne $W$ V. Tumor-like necrotizing granulomatosis of breast. Zentralb Allg Pathol 1983; 128: 101-6.

16 Deininger $\mathrm{H} \mathrm{K}$. Wegener granulomatosis of the breast. Radiology 1985; 154: 59-62.

17 Nishizawa T, Enomoto H, Hino T, Kijima T, Takemura T. Vasculitis of the breast with thrombocytopenia. F Rherumatol 1979; 6: 595-7.

18 Love S M, Schnitt S J, Connolly J L, Shirley R L. Benign breast disorders. In: Harris J R, Henderson I C, Hellman S, Kinne D W, eds. Breast diseases. Philadelphia: Lippincott, 1987: 15-53.

19 Hatteland K, Kluge T. Mondor's disease: A subcutaneous form of periarteritis nodosa? Acta Chir Scand 1965; 129: 67-71.

20 Binkley J S. Relapsing febrile nodular non-suppurative panniculitis. FAMA 1939; 113: 113-6.

21 Adair F E, Manger J T. Fat necrosis of the female breast: report of 110 cases. Am F Surg 1947; 74: 117-20.

22 Schnitt S J, Connolly J L, Harris J R, Cohen R B. Radiationinduced changes in the breast. Hum Pathol 1984; 15: 545-50.

23 Gansler T S, Wheeler J E. Mammary sarcoidosis: two cases and literature review. Arch Pathol Lab Med 1984; 108: 673-5. 